\title{
Online Buying Behaviour of Homemakers in Western Suburbs of Mumbai and Social Media Influence
}

\author{
${ }^{1}$ Indrila Goswami Varma, ${ }^{2}$ Ms. Rupa Agarwal
}

\begin{abstract}
Online shopping is a growing phenomenon worldwide and with increase in internet penetration India too is witnessing a surge in online shopping. Consumer buying behaviour is a widely researched area but online buying behaviour is a relatively new field of study. Marketers are trying to understand the online buying behaviour of Indian consumers so that they can look out for new ways of identifying distinct profitable customer segments and targeting them better. Marketers need to know who are the online customers, what are they buying online and why, what prevents them from buying online, what other factors affect their online buying behaviour, does social media have any influence on their buying behaviour.

Although very few studies have currently been done on Indian consumer-buying behaviour, and especially on the role of gender, there are indicators that different findings from those from the West may evolve.

This paper aims to identify the factors that affect the online buying behaviour of women particularly homemakers in Western suburbs of Mumbai .Educated, urban homemakers form a significant prospect for traditional retailers. The question that arises is whether this segment is also buying online or has remained untapped by the e-retailers? Research has examined the role of different factors on individuals ecommerce adoption, such as geography and store accessibility, perceived risk and online shopping benefits, typology of online stores, enjoyment and trust in Web sites, gender differences in attitudes toward online shopping, and impact of consumers socio-economic conditions (Sorce, Perotti, and Widrick 2005; Farag et) .Dennis, Morgan, Wright and Jayawardhena in the article, "The influences of social e-shopping in enhancing young women's online shopping behaviour", in the Journal of Customer Behaviour states that in the traditional world, women do most of the shopping but online, it is the reverse. Why should this be? Could it be that that online shopping (e-shopping) lacks the social experience of brick and mortar shopping.

An empirical study through online survey was conducted on 56 homemakers in western suburbs of Mumbai across the age group of 25-45 yrs. The quantitative and qualitative research aimed to analyse the buying attitudes of homemakers, influence of social media on their buying behaviour and other factors that effect their purchase decision online. It also attempts to explore the brick and mortar buying behaviour vs. online buying behaviour of the target audience. The study has its limitations as the sample size is too small to provide definitive information for marketing strategies to be developed, however it provides cues on which marketers can go into further depth to commission large scale research, given the opportunity that obviously exists.
\end{abstract}

Key words: Consumer behaviour, Social Media, Online buying, E-commerce, Internet shopping.

\subsection{Overview}

\section{Introduction.}

The Dot.com era was the precursor to the present day e-commerce era. The failure of the dot.com suggested that restructure of internal and external business processes to serve customers appropriately, the need to provide adequate technological and physical infrastructures, and the need to understand customer consumption processes in 'virtual' and physical environments is prerequisite for e-commerce.

As most retail businesses are moving towards online, brick- and- mortar to click- and -mortar and more and more people are beginning to live in the virtual world, it has become imperative for e-tailers to analyse who the target audience is and what they are doing, which social networking sites that they are on and finally how to leverage this and translate to good business. With advent of online stores like Myntra/ flipkart/snapdeal/ Jabong / Amazon etc crowding the web space the Indian consumer is spoilt for choice and convenience. Competition is getting tough. With the maturing of the ecosystem backed by robust infrastructure ( supply chain, broad band et.al.), more and more offline stores are rapidly getting into the online space. It is now or never for these retailers. With tremendous backing of VC funding towards online businesses, start-ups are taking on established retailers like never before. With advent of smartphones, 3G broadband internet services, better disposable income of Indians, other unfavorable factors effecting traditional shopping like parking issues, traffic snarls, long queues at billing points, more and more consumers are switching to online shopping for routine as well as fashion needs. The role of Social media on influencing the buying behaviour and creating instant WOM is also instrumental in creating customer confidence in shopping online. 
The purpose of this research is to provide an insight into the online buying behaviour of women particularly homemakers by investigating consumer beliefs and preferences about shopping on-line and in physical stores. A research model was developed and investigation into this study was performed through qualitative as well and quantitative methods.

\subsection{Online Shopping:}

Online shopping is the process of researching and purchasing products or services over the Internet. With the establishment of the World Wide Web and increase in the ownership of personal computers established retailers began to offer their products over the Internet as early as 1992.

Online shopping has several advantages over shopping in retail stores, including the ability to easily compare prices from a range of merchants, access to a wide selection of merchandise, being open $24 * 7$ and the convenience of not having to drive to a physical store. But despite that the online shopping cannot replace the experience of shopping in a retail store or the entertainment value of going to a mall or market. A customer who knows exactly what he or she wants can look it up online, read and compare the information, and purchase from the site that offers the best price or service. But a shopper, who is uncertain what to look for, or who just enjoys browsing through items on display, will prefer a retail store where the merchandise can be seen, handled and sampled. The décor, music and arrangement of goods in a retail store create a multi-dimensional shopping environment that cannot be replicated online. For many people, going shopping at a mall, department store or market is a form of entertainment and a social experience. Many people who are currently unfamiliar with computers and do not feel comfortable using the Internet to shop are not likely to change their habits.

The growth in future will come through improvements to the shopping process on existing Web sites; the implementation of more online shopping sites by existing retailers; the coming of age of a younger, more technology-oriented generation; and the introduction of novel goods, services and online shopping experiences. The growth of online shopping in developing nations like India will occur as more people acquire personal computers and credit cards. (ukessays.com)

\subsection{Indian Scenario}

The latest round of I-Cube, a research conducted by IAMAI and IMRB International in June 2013, indicates that the Internet usage in India has gone up. The internet users increased from 205 million in October 2013 to an estimated 213 Million in December 2013. The number of internet users in urban India was estimated to reach 141Million by December 2013 and in rural India to 72 Million. Mobile internet too, has garnered a huge base among the presents a huge opportunity for growth.

While the Internet and the World Wide Web are continuing to expand at a rapid pace, the development of electronic commerce has been slower. Surveys indicate many Indian Internet users employ the developing interactive medium to shop or browse for information on products and services, but a far smaller percentage has actually made purchases online.

Online shopping though a small proportion of the Internet activity is believed to increase in the coming years. Some of the prominent factors leading the change are greater Internet penetration, fall in prices of hardware, fall in the price of Internet communication, development of better and more reliable technologies, mobile penetration and increased awareness among the users.

According to IAMAI online retailing reached 12.6 billion dollars in the country last year with an annual growth increase of $32.63 \%$. As policy and FDI issues are addressed and delivery logistics improve, further growth is expected. The IAMAI estimates number of online retailers to be over 1Million across wide range of categories. This testifies to the efficiencies, lower capital costs and deep out reach that online market place provides to the retailers. Indian online retail space is following global trajectory and proving to be sustainable and profitable marketing and distribution model. IAMAI said that , while technology platforms tend to be run from city centers, the bulk of logistical management such as go downs and deliveries are being handled from tier 2 and tier 3 cities.

The ecommerce market in India is expected to grow by 33 per cent to reach Rs 62,967 crores by the end of 2013 predicted a report released by the Internet and Mobile Association of India (IAMAI) and IMRB International. The ecommerce market was valued at Rs 47,349 cr in 
December 2012 .

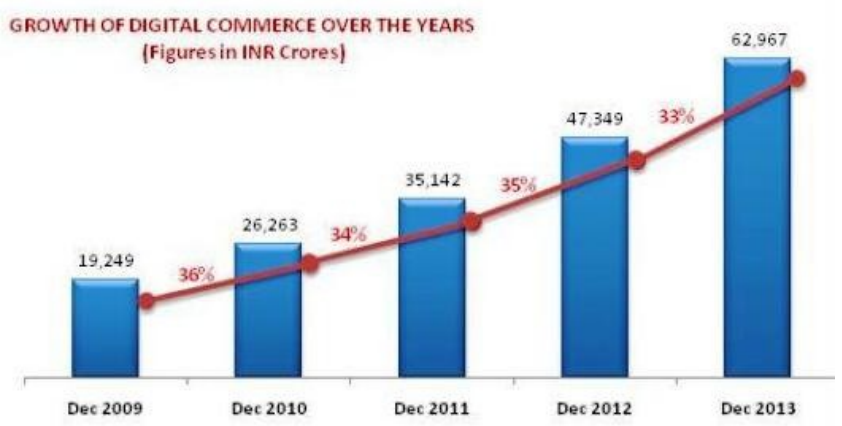

Source: IAMAI-IMRB International

As per the findings, Online Travel (booking rail, air, bus tickets, hotel accommodations, tour packages) comprised a majority 71 percent of the whole Digital-Commerce pie in 2012. While e-tailing, which includes purchases of various consumer products/services constituted 16 percent of the overall share.

Table 2 :

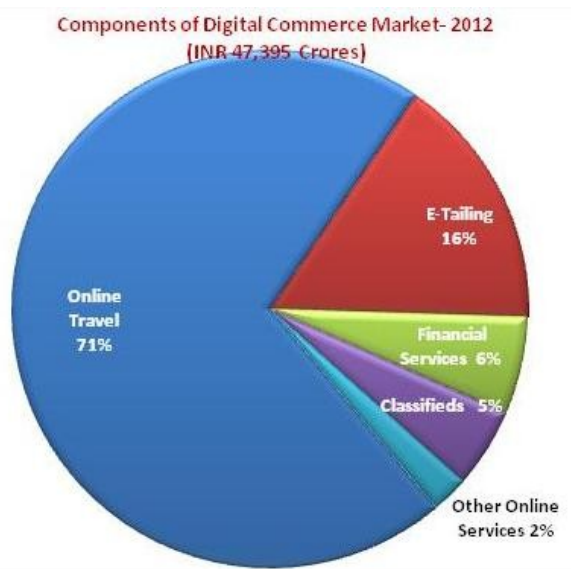

Financial Services, which include services such as paying insurance premiums and renewals, paying utility and mobile bills, trading shares and securities amounted to 6 percent of the overall share. B2B and B2C Classifieds (jobs, matrimony, car, real estate etc.) contributed 5 percent, whereas other online services such as online entertainment ticketing, online food delivery, buying discounts/deals/vouchers etc. constituted 2 percent of the overall digital commerce market in 2012.

The Nielsen Global Online Shopping Report looks at how consumers shop online: what they intend to buy, how they use various sites, the impact of social media and other factors that come into play when they are trying to decide how to spend their money.

\section{Summary Of The Key Findings}

- More than eight out of ten Indian online consumers plan to shop online in the next twelve months

- More than a quarter indicate that they spend upwards of 11 percent of their monthly shopping expenditure on online purchases

- 71 percent Indians trust recommendations from family when making an online purchase decision, followed by recommendations from friends at 64 percent and online product reviews at 29 percent

- Half the Indian consumers (50\%) use social media sites to help them make online purchase decisions.

- Online reviews and opinions are most important for Indians when buying Consumer Electronics (57\%), Software (50\%), and a Car (47\%).

- More than four in ten Indians are more likely to share (post a review/ Tweet/ review) a negative product or service experience online than they were to share a positive experience

- In the next six months Indians are most likely to buy Books (41\%), Airline ticket/reservations (40\%), and Electronic equipment like TV, Camera, etc. (36\%) online

- When shopping online, one third of Indians (33\%) purchase most frequently from websites which allow them to select products from many different stores. 
According to a survey conducted by Nielsen, Indian netizens are the third largest credit card users for online shopping next to only Turkey and Ireland (Achille 2008; Express India 2008). Among online shoppers, the highest percentage comes from South Korea (99\%), followed by the United Kingdom (97\%), Germany (97\%), Japan (97\%), and the United States (94\%). Internet use in Asia between 2000 and 2009 has increased more than 5 times and accounts for 42.2 percent of users. India stands fourth globally, with 4.9 percent being Internet users as compared to China, which has 20.8 percent. The United States has 13.1 percent users, followed by Japan at 5.5 percent (Internet World Statistics 2009).

Growth in Internet accessibility has increased its adoption for browsing and shopping among Indians. However, with a population of over a billion, the number of Internet users is still quite small. It is to be noted that among 71 million users, only 52 million are active users. Indian youth continue to drive the surge of Internet usage and comprise a large section of total users. Among youths, the Internet is primarily used for searching general information and browsing entertainment Web sites (Ganguly2009).

According to report from Associated Chambers of Commerce \& Industry of India, in the India, two metros are driving growth with Delhi contributing $24 \%$ of the E-sales and Mumbai contributing $20 \%$ of the Esales (cited in blog catalog, 2010).

Mahmood, Bagchi, and Ford (2004), in their research on online shopping in different countries, suggested that trust and economic conditions have positive and significant impact on consumer's online shopping behavior.

\subsection{The Online Buying Process}

According to marketing expert Phillip Kotler, buying stages can be identified as pre-purchase stage, purchase stage and post-purchase stage.

Within the pre-purchase stage of online buying, consumers search for information about goods and services and they evaluate different alternatives. Two important issues are to be discussed here. First, there are the attributes of information: accessibility of information and the quality of information. Information accessibility is referred as the ease of finding relevant information for the buying decision making. When deciding to collect information online, consumers have many ways of finding the relevant information: searching information using a search engine, directly visiting the online vendor's website, reading previous consumers reviews posted on forums, social networks or blogs etc. Easy access to price and product information is one of the main benefits of searching for information on the Internet.

Due to the abundant availability of information on the Internet, consumers can make better informed purchase decisions. But abundance of online information does not imply quality. Quality information has been defined as being up-to-date, complete, detailed, reliable, and trustful and communicated in a proper format.

Within the purchase stage of the online buying process, consumers order and pay for the goods and services bought online. The ordering process depends highly on the reliability of the ecommerce platform and the payment process depends highly on the security of the e-commerce platform. Online buying does not offer instant satisfaction since there is a temporal separation between ordering goods and services and actual consumption (Suki and Suki, 2007, p. 83). Of course, this is not the case of digital products and services that can be downloaded and instantly used .But for the rest of the goods and services, the consumer has to wait for the delivery of the acquisition. This could justify the importance of delivery in the post-purchase stage. The delivery time, the delivery of the right product regarding its attributes and performance is highly associated with post-purchase satisfaction.

Also, post-purchase customer relationships will weight high when considering this transaction specific satisfaction. Consumers may inquire about the delivery status of their order or ask additional information about the goods and services. In those cases when consumers are not satisfied with the product that they have purchased, returning policies play a significant role in regard to the post-purchase satisfaction since returning policies are a main concern for online consumers.

According to a survey conducted by Nielsen, Indian netizens are the third largest credit card users for online shopping next to only Turkey and Ireland (Achille 2008; Express India 2008). Among online shoppers, the highest percentage comes from South Korea (99\%), followed by the United Kingdom (97\%), Germany (97\%), Japan (97\%), and the United States (94\%). Internet use in Asia between 2000 and 2009 has increased more than 5 times and accounts for 42.2 percent of users. India stands fourth globally, with 4.9 percent being Internet users as compared to China, which has 20.8 percent. The United States has 13.1 percent users, followed by Japan at 5.5 percent (Internet World Statistics 2009).

Growth in Internet accessibility has increased its adoption for browsing and shopping among Indians. However, with a population of over a billion, the number of Internet users is still quite small. It is to be noted that among 71 million users, only 52 million are active users. Indian youth continue to drive the surge of Internet usage and comprise a large section of total users. Among youths, the Internet is primarily used for searching general information and browsing entertainment Web sites (Ganguly2009). 
Information communication technology (ICT) has grown from being a concentrated technology to a mass or social technology used for marketing (Adams and Ghose 2003). More and more people around the world browse the Internet to get information about products and services. However, recent research indicates that there is limited use of the Internet for shopping.

\section{Advantages and disadvantages of online shopping \\ Advantages}

Convenience - Online shopping is possible $24 * 7$ as consumers have Internet access both at work and at home. Other establishments such as internet cafes and schools also provide internet access. In contrast, visiting a conventional retail store requires travel and must take place during business hours.

Information and reviews - Online stores must describe products for sale with text, photos, and multimedia files, whereas in a physical retail store, the actual product and the manufacturer's packaging will be available for direct inspection. Some online stores provide or link to supplemental product information, such as instructions, safety procedures, demonstrations, or manufacturer specifications as well as how-to guides designed to help consumers decide which product to buy. Some stores even allow customers to comment or rate their item

Price and selection - Advantage to consumers is ability to quickly seek out deals for items or services provided by many different vendors.

Advantage for retailers is the ability to rapidly switch suppliers and vendors without disrupting users' shopping experience.

\section{Disadvantages}

Fraud and security concerns - Given the Consumers are at higher risk of fraud due to lack of ability to inspect merchandise before purchase. Merchants also risk fraudulent purchases using stolen credit cards or fraudulent repudiation of the online purchase.

Lack of full cost disclosure - While it may be easy to compare the base price of an item online, it may not be easy to see the total cost up front. Additional fees such as shipping are often not be visible until the final step in the checkout process. The problem is especially evident with cross- border purchases, where the cost indicated may not include additional fees that must be paid upon delivery such as duties and brokerage.

Privacy - Privacy of personal information is a significant issue for some consumers. Different legal jurisdictions have different laws concerning consumer privacy, and different levels of enforcement. Many consumers wish to avoid spam and telemarketing which could result from supplying contact information to an online merchant. In response, many merchants promise to not use consumer information for these purposes, or provide a mechanism to opt-out of such contacts.

Many websites keep track of consumer shopping habits in order to suggest items and other websites to view. Brick-and-mortar stores also collect consumer information. Some ask for a shopper's address and phone number at checkout, though consumers may refuse to provide it. Many larger stores use the address information encoded on consumers' credit cards (often without their knowledge) to add them to a catalog mailing list. This information is obviously not accessible to the merchant when paying in cash..

Hands on inspection - Only simple pictures and/or descriptions of the item are all a customer can rely on when shopping on online stores. If the customer does not have prior exposure to the item's handling qualities, they will not have a full understanding of the item they are buying. However, written and video reviews are readily available from consumers who have purchased similar items in the past.

Because of this, many consumers have begun going to real-world stores to view a product, before purchasing online, a practice known as showrooming.

\subsection{Consumer Behaviour}

The term consumer behavior is defined as the behavior that consumer display in searching for, purchasing using, evaluating and disposing of products and services that they expect will satisfy their needs. Marketers need to understand why consumers make the purchases that they make, what factors influence consumer purchases, the changing factors in our society. A firm needs to analyze the what, where, when and how consumers buy.

It is clear that better understanding the consumer buying behavior through studying and identifying their needs leads to huge long term benefits to the businesses. However, as stated by Kotler et al (2005) it is essential to mention that despite the great efforts to learn and understand the buying behavior of consumers, it is very difficult to identify the exact reasons why a consumer purchases and prefers one product or service over another one and now one channel over the other. This is because consumers sometimes make purchasing decisions based on their emotional beliefs which they even themselves are not well aware of.

There are five stages of buying process .they are. 
1) Identify the problem: The first stage of the decision-making process is that people can feel the difference between current and desired situation, so trying to resolve these differences.

2) Data collection: For solving this problem collect information. This information can be internal (experiences) and external (family, exhibits, etc.)

3) Assessment Options: After gathering information, the consumer is ready to make a decision. At this point, he should be able to evaluate different options and choose products that meet the demands of him.

4) Purchase: This stage is the stage that all marketing activities are the result. Consumer at this stage, according to the information already obtained, Select a product that feels satisfy his need and buys it.

5) After purchase behavior: Consumer compare purchased products with ideas, products, competitors, perceptions and expectations of the product and two satisfaction and dissatisfaction, which may appear different reasons.

\subsection{Consumer Behaviour And Consumer Socialisation}

\section{Literature Review:}

Consumer behaviour is a complex area, but marketers do need to try to find out as much as they can about who their customers are in order to identify their needs, how they behave, what influences them to make a decision to buy and what processes they follow when selecting a product/service/channel. This information is required so that marketers can target their marketing activities as precisely and cost effectively as possible. There are many influences on purchasing behaviour, including social (culture, sub-culture, social class, reference groups, and family), technological, political, economic and personal factors (motivation, personality, self-image, perception, learning, beliefs and attitudes). (Stephen\& Grant, 2005)

An attitude has been defined as 'an overall favourable or unfavourable evaluation of a product or service'. Attitudes are basically people's likes and dislikes regarding products, services, ideas, brands, organisations and people. Attitudes are learned through the socialisation and cognitive processes and can therefore be changed. They act as a framework on which we build thoughts and beliefs. However, changing attitudes can be difficult, as they fit into a pattern, and to change one attitude may require radical adjustments to be made to others. ( Grant\& Stephen 2005)

A consumer's attitude is very influential in the decision-making process, and attitudes are shaped by many factors, including education, economic circumstances, family, age, experience, the law and social background .Much consumer behaviour is performed under the influence of others.(Grant \& Stephen) The very foundation of human behaviour is learning from others'. Today a popular means of staying connected with the outside world is social networking sites. World has become a smaller place and use of social networking sites is increasing day by day as a medium of keeping in touch, staying abreast of developments and communicating one-to-one, one-to-many and many to many on a common platform.

The reasons for using the Internet for shopping are triggered by diverse attitudes and motivations. Consumers seek value, temporal benefits, flexibility, and possibility of exploring products in online environments. Consumers search for convenience in online transactions as it gives them flexibility to browse websites at leisure. According to a research done in Taiwan it was found that website design, website reliability, website security, and website customer service are the four dominant characteristic factors that influence consumer perceptions of online purchasing. Besides, the four types of online buyers (trial, occasional, frequent and regular online buyers) have different perceptions of these website characteristics.

Research shows that many consumers have yet to adopt the attitude and personal habits necessary for on-line shopping, and many more who have at least embraced the internet for acquiring information still do not use it as a means for purchasing products and services. However, despite these limitations to on-line shopping, all available evidence suggests that purchases on the internet will increase dramatically in the next few years. As the technological infrastructure improves, consumers will become more comfortable shopping on-line, and vendors will learn how to take advantage of the internet's strengths to market and sell goods and services more effectively (G. J. Browne et al., 2004).

Research has examined the role of different factors on individuals ecommerce adoption, such as geography and store accessibility, perceived risk and online shopping benefits, typology of online stores, enjoyment and trust in Web sites (Grewal, Lindsey-Mullikin, and Munger 2004; Gefen 2004; Lee, Cheung, and Chen 2005; Ha and Stoel 2009), gender differences in attitudes toward online shopping , and impact of consumers socio-economic conditions (Sorce, Perotti, and Widrick 2005; Farag et)

Internet access has affected consumers preferences for using it for browsing and surfing (Soopramanien and Robertson 2007) and searching for new product information (Moe and Fader 2004). Alba and colleagues (1997) suggested that consumer shopping behavior in online interfaces differs from the traditional retail environment. 


\subsection{Factors Affecting Online Buying Decisions : Situational factors}

Attitude and consumers intention to shop on the Internet is guided by a wide variety of situational factors, like time pressure,lack of mobility, geographical distance, need for special items and attractiveness of alternatives. To most consumers important attributes of online shopping are convenience and accessibility (Wolfinbarger and Gilly, 2001): because consumers can shop on the Internet in the comfort of their home environment, it saves time and effort, and they are able to shop any time of the day or night.

\section{Product characteristics}

Online shopping decisions of consumers are also influenced by the type of product or service under consideration. The lack of physical contact and aid in shopping on the Internet is one factor that influences this suitability. Another factor is the need to feel, touch, smell, or try the product, which is not possible when shopping online. Following this, clearly standardized and familiar products such as books, videotapes, CDs, groceries, and flowers, have a higher potential to be considered when shopping on the Internet, especially since quality uncertainty in such products is virtually absent, and no physical assistance or pre-trial is needed (Grewal et al., 2002; Reibstein, 1999).

\section{Previous online shopping experiences}

Intention to shop online is also influenced by consumers Internet shopping history (Shim et al., 2001). It is demonstrated by past research findings that prior online shopping experiences have a direct impact on Internet shopping intentions (Eastlick and Lotz, 1999; Weber and Roehl, 1999). Helson (1964) suggests that an individual response to a judgmental task is based on three aspects:

(1)Individuals past experiences.

(2)The context or background.

(3)The stimulus.

\section{Trust in online shopping}

Lack of trust is one of the most frequently cited reasons for consumers not shopping on the Internet (Lee and Turban, 2001). Since this shopping medium is relatively new and most of them have only little experience with it, shopping on the Internet provides a challenge to many consumers. Rotter (1971) has found that in novel situations, people rely on their general disposition to trust. The most salient source of trust in a retail setting is the salesperson, where consumer trust is dependent on the salesperson expertise, likeability, and similarity to the customer (Doney and Cannon, 1997)

Literature shows that social media has empowered the consumer, who has control over the extent and type of messages they are exposed to. Another important finding is that the influence of friends is highly prevalent on SNSs. Respondents react and listens to their friends' comments, which in turn affects their attitudes. This influence extends to products and services as well. Thus, connections do have the capacity to influence others' opinions and attitudes towards companies, products and brands. The strength of influence between connections on SNSs is clearly evident, yet while this potential exists; it has yet to be realized by the marketer.

\subsection{Gender and shopping orientations}

Shopping orientations is an area in consumer behaviour that has been pursued extensively in the literature. Stone (1954) was considered a pioneer when he suggested a shopper typology, namely, the economic shopper, the personalizing shopper, the ethical shopper and the apathetic shopper. According to Westbrook and Black (1985), when consumers shop they are motivated by purchase needs, experiential needs or a combination of both. Shim (1996) proposed that there are three basic shopping traits: utilitarian, social/conspicuous or undesirable orientations. Utilitarian/economic styles usually pertain to the 'perfectionism' and 'value consciousness' traits, because they favour quality and/or price. They generally dislike shopping or are neutral towards it. In contrast, the 'recreational' trait is associated with the traits of novelty/fashion consciousness, impulsiveness and shopping as leisure. In this study, the four types of shopping orientations that evolved and that were studied were: the utilitarian shoppers, the window-shoppers, the economic shoppers and the recreational shoppers. The utilitarian shoppers generally do not enjoy shopping; they make purposeful visits to the mall and do not wish to linger there any more than they have to. The window-shoppers enjoy the visual treat in malls but are not overly excited by shopping or given to impulse purchase. The economic shoppers are price sensitive and having concern for finances. Accordingly, they shop around for the lowest price.

Although very few studies have currently been done on Indian consumer-buying behaviour, and especially on the role of gender, there are indicators that different findings from those from the West may 
evolve. In India shopping dynamics can be different. Here, shopping is a family activity: nearly $70 \%$ of shoppers always go to stores with the family, and $74 \%$ see shopping as the best way to spend time with the family. This preference for family-oriented shopping was found to be consistent across age groups, income segments, regions and city sizes. (Sheth and Vittal, 2007).

In the traditional world, women do most of the shopping but online, it is the reverse (Ballard and Mander 2006; Dennis et al. 2002b; OFT 2007). Why should this be? Could it be that that online shopping (eshopping) lacks the social experience of brick and mortar shopping? There is evidence that females and in particular, young adults, regard the social aspect of shopping as an important element (e.g. Dholakia 1999). Kolesar and Galbraith (2000) found that Internet retailers (e-retailers) have difficulty in satisfying customers' higher-level needs for personal interaction. Yet the Internet is the new social space for young females (Anonymous 2007; Social Networks 2007). We suggest that there is a major opportunity for e-retailers to combine social networking with e-shopping.

\section{Social Media Influence}

Business today is being transformed from a transactional relationship to a social relationship. The advent of social media has opened a new avenue of marketing for corporations. The traditional "word-ofmouth" publicity has been replaced by the "word-of-web", as consumers are increasingly referring to social media sites before making a purchase, greatly influencing buying behavior. Though most companies these days have an official website which has complete information about their products, consumers usually engage with a company after reading reviews and feedback from existing customers. Before buying a product, every consumer wants to make sure that the product is the best in its class, and offers good value for money. This is where social media plays an important part in defining consumer behavior. People who have already used the product describe their experience - its strengths, weaknesses etc., and this helps in disseminating information.Social proof is the new currency of credibility.

A 2012 Nielsen survey indicated that $92 \%$ of people globally trust word-of-mouth recommendations from friends and family $85 \%$ of consumers say that they refer to online reviews before making a purchase at a local business. People are more likely to trust those who give an impartial account of a product rather than a celebrity who is paid to endorse the product. Social media enables people from all over the world to form a community of consumers, giving them the power to harm or herald a company.

The current literature on consumer online purchasing decisions has mainly concentrated on identifying the factors which affect the willingness of consumers to engage in Internet shopping. In the domain of consumer behaviour research, there are general models of buying behaviour that depict the process which consumers use in making a purchase decision. These models are very important to marketers as they have the ability to explain and predict consumers' purchase behaviour. The classic consumer purchasing decision-making theory can be characterized as a continuum extending from routine problem-solving behaviours, through to limited problemsolving behaviours and then towards extensive problem-solving behaviours [Schiffman et al., 2001]. The traditional framework for analysis of the buyer decision process is a five-step model. Given the model, the consumer progresses firstly from a state of felt deprivation (problem recognition), to the search for information on problem solutions. The information gathered provides the basis for the evaluation of alternatives. Finally, post-purchase behaviour is critical in the marketing perspective, as it eventually affects consumers' perception of satisfaction/dissatisfaction with the product/service. This classic five stage model comprises the essence of consumer behaviour under most contexts. Nevertheless, the management of marketing issues at each stage in the virtual environment has to be resolved by individual E- marketers. Peterson et al. [1997] commented that it is an early stage in Internet development in terms of building an appropriate dedicated model of consumer buying behaviour. Decision sequences will be influenced by the starting point of the consumer, the relevant market structures and the characteristics of the product in question. Consumers' attitude towards online shopping is a prominent factor affecting actual buying behaviour.

Source: Jarvenpaa Journal of Electronic Commerce Research, VOL. 6, NO.2, 2005

Todd [1997] proposed a model of attitudes and shopping intention towards Internet shopping in general. The model included several indicators, belonging to four major categories; the value of the product, the shopping experience, the quality of service offered by the website and the risk perceptions of Internet retail shopping. In the research conducted by Vellido et al. [2000], nine factors associated with users' perception of online shopping were extracted. Among those factors the risk perception of users was demonstrated to be the main discriminator between people buying online and people not buying online. Other discriminating factors were; control over, and convenience of, the shopping process, affordability of merchandise, customer service and ease of use of the shopping site. In another study, Jarvenpaa et al. [2000] tested a model of consumer attitude towards specific web base stores, in which perceptions of the store's reputation and size were assumed to affect consumer trust of the retailer. The level of trust was positively related to the attitude toward the store, 
and inversely related to the perception of the risks involved in buying from that store. Jarvenpaa et al. [2000] concluded that the attitude and the risk perception might affect the consumer's intention to buy from the store.

Consumer risk perceptions and concerns regarding online shopping are mainly related to aspects involving the privacy and security of personal information, the security of online transaction systems and the uncertainty of product quality. Trust is interwoven with risk [McAllister, 1995]. One of the consequences of trust is that it reduces the consumer's perception of risk associated with opportunistic behaviour by the seller [Ganesan, 1994]. Lack of trust is frequently reported as the reason for consumers not purchasing from Internet shops, as trust is regarded as an important factor under conditions of uncertainty and risk in traditional theories.

Mayer et al. [1995] developed a model which combines traditional marketing philosophy on consumer motivation to buy and the trust model. In this model, trust propensity; which is a personality trait possessed by buyers; is an important antecedent of trust. In Internet shopping, there is not much information available to the buyer regarding the seller, prior to purchase. A buyer with a high propensity to trust will more likely be a potential customer than a buyer with a lower propensity. Mayer et al. [1995] proposed that ability, benevolence and integrity constitute the main elements of trustworthiness. Ability refers to skills, competencies and characteristics that a seller has in a specific domain. In this context, sellers need to convince buyers of the competence of their companies in the Internet shopping business. Benevolence is the extent to which the seller is perceived by the buyer as wanting to 'do good'. Sellers have to convince buyers that they genuinely want to do good things for buyers, rather than just maximize profit.

\subsection{Openness to change:}

Openness to change focuses on diversity and thrill. Internet shoppers have been found to be more innovative, impulsive, convenience seeking and less risk averse than non-Internet shoppers (Donthu and Garcia, 1999). A similar pattern has been obtained in relation to online grocery shopping. Hansen (2005) showed that non-online grocery shoppers regard online grocery shopping as less compatible with their daily lives as compared with adopters of online grocery shopping.

\subsection{Self-transcendence and self-enhancement}

Morganosky and Cude (2000) instituted that online grocery shoppers prefer convenience and time saved as the primary reasons for shopping online. As an additional advantage of online grocery shopping, compared with conventional shopping, Ramus and Nielsen (2005) found that consumers emphasize that this form of shopping allows one to shop without leaving home and to order groceries in a situation which is less stressful than going to the grocery store during rush hours. Moreover, it was also detected that many consumers are concerned with the missing social interaction with other people when shopping online (Hansen, T. 2006). Self-enhancement focuses on wealth and power and getting thing done effectively, whereas self-transcendence emphasizes equality and maintaining good social relations.

Substantiation by Shang, et al. (2005) suggests that online shopping is not much of a goal-oriented activity rather than a result from cognitive absorption experiences from the Internet. Cognitive absorption is a personality characteristic that influences perception, and especially perceptual differentiation (Antonides, 1998). The use of internet is rapidly growing every year. Consumers are exposed to online advertisement and online shopping of goods. According to research online shopping has a notable improvement in many parts of the world. Continental Research in 2008 (cited in blog catalog, 2010) shows that, 9000 crores of Indian consumers had experienced online transactions such as online shopping or paid downloading.

\subsection{Complexities in online shopping:}

In spite of the fact that online shopping has several advantages over the traditional method, there are also few pitfalls pertaining to internet buying. In virtual shops, the consumer is not able to see and check the product quality, as would be the case in physical store (Childers 2001; Verhoef and Langerak 2001). Instead the customer should touch and feel the information from product descriptions. Buying products on internet seems to be more complex decision as it is more difficult for the consumer to form an impression as to whether the products on offer are appropriate (Raijas 2002). The second area of complexity concerns the mode of payment for the ordered products. Most of the consumers who are used to pay by cash at a checkout may find the electronic transfer and security checks unfamiliar and more complex.

\subsection{Drawbacks of online shopping:}

According to Wilson-Jeanselme (2001) the greater convenience benefits afforded by the online experience can 'leak away' as a result of four sets of ineffective or ineffective operational practices such as, a poor internet interface, ineffective management of customer demand information, badly planned warehouse, 
poor physical flow of products from store. These sorts of poor consumer experiences would create a bad image on consumers mind in spite of the greater convenience online. Grocery store that allows shopping online typically charges with a delivery fee, which is an additional cost to the customer (Albright, 2007). If the consumer's motivation to shop online was to save money spend on fuel and parking, and his motivation was not satisfied then probability of that consumer not shopping online was also high. Online shoppers have to purchase or spend a minimum amount of money in order to have their groceries delivered (Albright, 2007). Consumers who are looking to purchase grocery for a quantity less than the minimum criteria, they are left with no option other than choosing physical shopping. Consumers has an impression that they could save time by online shopping but eventually the consumer has to stay at home or at delivery address until the ordered grocery items have been received. If the consumer has to meet with some other appointment and the products delivered were not on time, the possibility that consumer creates bad image not only with online service (e.g. Child brand) but also with their physical store (parent brand) (Aaker and Keller, 1990). Returning or exchanging groceries bought online can be more difficult than making a return or exchange of products that have been purchased in store (Albright, 2007).

Finally Men may benefit from shopping online more than women do because it suits the purposeful masculine style more, e.g. finding the best deals quickly (Dennis and McCall 2005; Underhill 1999). One study reported that $22 \%$ of men shop online at least once a week or more compared to $14 \%$ of women (OFT 2007). This indicates that retailers need to focus on how to encourage more women to shop online regularly, which is the reason why this study focuses on women's attitude and behaviour intentions towards e-shopping sites.

\section{Research Methodology}

The project report is an empirical study on online buying behaviour of homemakers in Mumbai, western suburbs. $\square$.

The specific objectives of this research are:

1. To know the perception/ attitudes of homemakers towards online buying.

2. To identify key factors influencing online shopping purchase behaviour.

3. To understand impact of social media and its influence on online buying behaviour of homemakers.

This report has followed exploratory research design. Exploratory research is a form of research conducted for a problem that has not been clearly defined. This research relies on secondary research such as reviewing available literature, data, qualitative approaches focus groups interview and e-survey.

In this research Non- Probability Judgment Sampling and snowball sampling was used because the respondents were homemakers in western suburbs of Mumbai. The study was conducted on 56 home makers in western suburbs of Mumbai and the surveys mailed and distributed among the Internet users chosen.

\section{Research Instrument:-}

Both Quantitative as well as Qualitative research methods were used.

Questionnaire was used which contained open as well as close ended questions. Questionnaire was designed in order to know the perception and behavior of customers towards online buying, the factors/attributes which influence them to buy online. It was designed in simple and understandable language basically to know there point of view about the online buying. Survey was conducted in Mumbai itself. Certain Questions were made on 5-point likert scale (strongly disagree, disagree, neutral, agree, strongly agree) in order to know the opinion of the respondents.

Qualitative research allows researchers to formulate interpretations of the subjects under study and to give representations of these interpretations in order to add to a body of knowledge (Wright 2008). This was operationalised in the form of semi-structured questionnaire and focus group. Focus groups are particularly appropriate for this type of research as they provide insight and depth into the attitude and behaviour intentions of a group of participants (Krueger 1994).

Under Qualitative method, a focus group interview was conducted with 3 groups of 3 homemakers each. The research, in the controlled environment, made the participants feel 'relaxed and unthreatened' and took the form of three, one-hour long, structured focus group interviews. Each interview consisted of two to three homemakers aged between 30 and 45 years. A total of 5/6 open-ended questions were formulated to identify what influences homemakers to buy online.

As this was a small convenience sample, it was not appropriate to apply statistical techniques to the results; instead, content analysis techniques were employed to answer the research questions. The responses were recorded, transcripted and analysed which formed the basis of the results presented. 


\section{Limitations}

The main limitation of using convenience sampling is its lack of representativeness. Since this study was exploratory and limited to the homemakers in western suburbs in Mumbai, finding can only be used as a guide for further research into this area. The purpose of the next stage in the research is to extend it to all homemakers in India.

\section{Scope for Further Research :}

Based on the findings, quantitative and qualitative research should be undertaken to allow the generalisation of results in relation to the population of Indian homemakers as a whole, thus enabling more definitive conclusions to be drawn. A parallel study on the buying behaviour of professional women could draw interesting differences in online shopping behaviour.

\section{Data Analysis And Interpretation}

Primary data was collected through questionnaires.

Secondary data was collected through internet, articles and journals

\subsection{Quantitative Analysis}

\section{Q1: How often do you buy products online?}

TABLE : 1

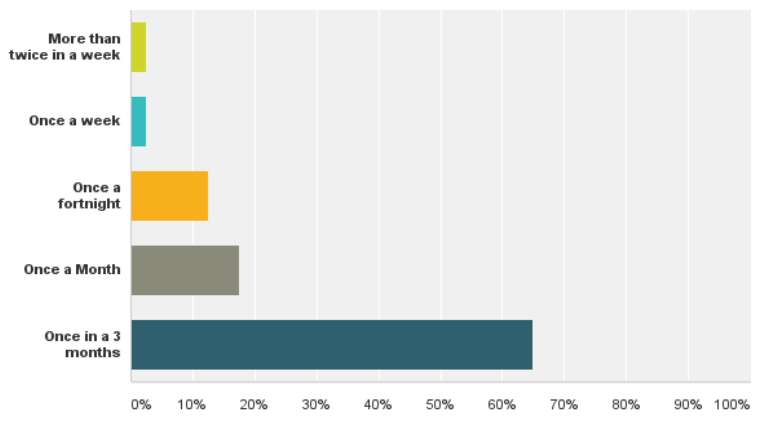

\begin{tabular}{|c|c|c|}
\hline Answer Choices & Response & \\
\hline More thantwice in a week & $2.50 \%$ & 1 \\
\hline Once a week & $2.50 \%$ & 1 \\
\hline Once a forthight & $12.50 \%$ & 5 \\
\hline Once a Morth & $17.50 \%$ & 7 \\
\hline Once in a 3 morths & $65.00 \%$ & 26 \\
\hline Total & & 40 \\
\hline
\end{tabular}

From the survey it emerges that $65 \%$ of homemakers buy products online once in 3 months. This shows a low propensity of homemakers towards online shopping. Only about $2.5 \%$ buy more than twice a week. This finding implies that a potential segment which is internet savvy educated and with considerable disposal income is not buying online and remains untapped by e-marketers.

\section{Q2: What types of products do you typically buy online?}

\section{TABLE :2}

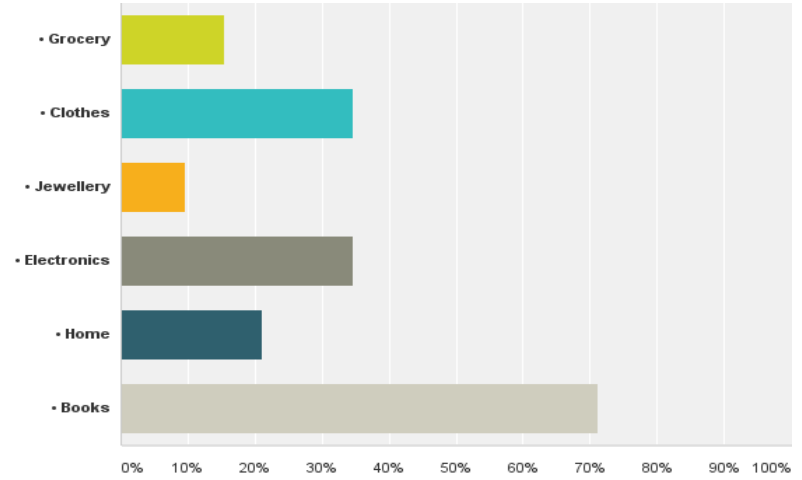

\begin{tabular}{l|lc}
\hline Answer Choices & Responses \\
\hline More than twice in a week & $2.50 \%$ & 1 \\
\hline Once a week & $2.50 \%$ & 1 \\
\hline Once a fortnight & $12.50 \%$ & 5 \\
\hline Once a Morth & $17.50 \%$ & 7 \\
\hline Once in a 3 months & $65.00 \%$ & 26 \\
\hline Total & & 40 \\
\hline
\end{tabular}

The study depicts that $71.15 \%$ buy books online followed by electronics and clothes at $34.62 \%$ Jewellery is least preferred to be bought online at $9.62 \%$. This shows that homemakers are more confident to indulge in low value merchandise.

As per The Nielsen Global Online Shopping Report, 2010, Indians are most likely to buy Books (41\%), Airline ticket/reservations (40\%), and Electronic equipment like TV, Camera, etc. (36\%) online. 
Therefore, it is quite clear that apart from other issues, homemakers also prefer to stay away from online purchase of those products that require touch, feel and need customization (Jewellery, clothes etc).

\section{Q3: Which online retailers do you typically use?}

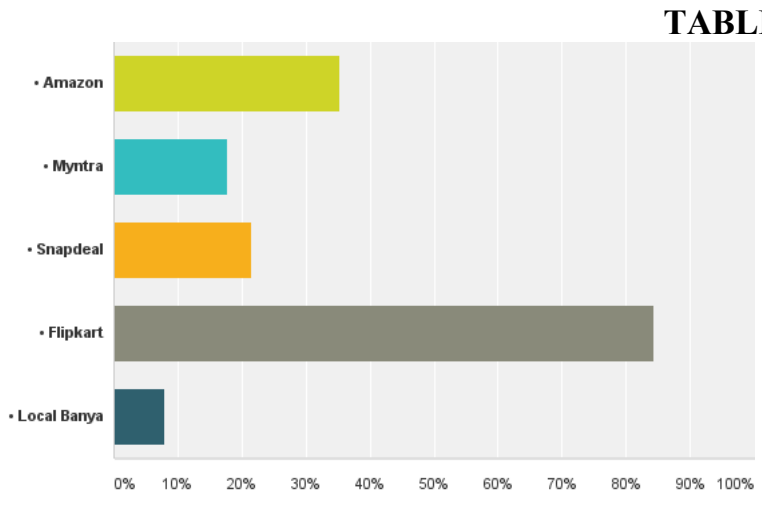

\begin{tabular}{|c|c|c|}
\hline \multirow{2}{*}{$\begin{array}{c}\text { Answer Choices } \\
\text {-Amazon }\end{array}$} & \multicolumn{2}{|c|}{ Responses } \\
\hline & $35.29 \%$ & 18 \\
\hline - Myntra & $17.65 \%$ & 9 \\
\hline - Snapdeal & $21.57 \%$ & 11 \\
\hline - Fliplat & $84.31 \%$ & 43 \\
\hline - Loca Banya & $7.84 \%$ & 4 \\
\hline Total Respondents & & \\
\hline
\end{tabular}

Q4 :Which, according to you, is the most trusted online retailer and why?

Flipkart is the most preferred e-tailer for homemakers at $84.31 \%$ followed by Amazon at $35.2 \%$. Grocery online retailer Local Banya is the least preferred at $7.84 \%$ only.

Flipkart as per the survey emerges to be providing best in terms of customer service, prompt delivery, good return policy as well as good quality merchandise.

As per Crisil, In India, Flipkart and Snapdeal dominate the online marketplaces.

\section{Q5: What triggers you to buy online ?}

\section{TABLE :5}

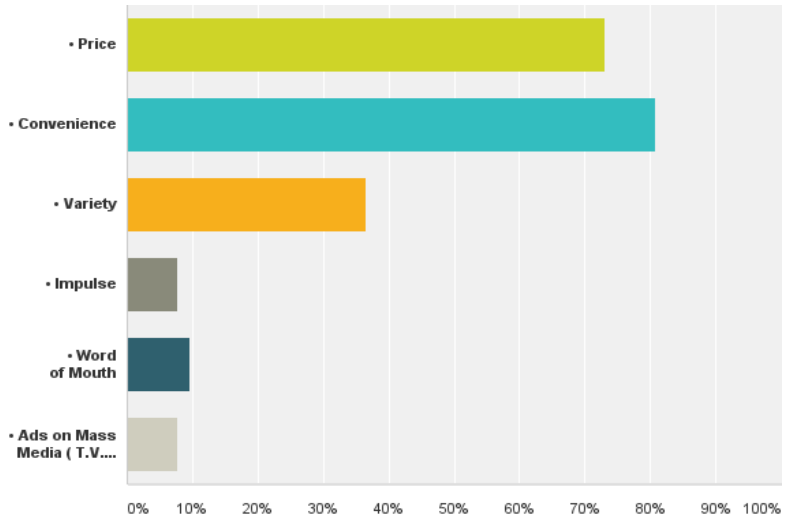

\begin{tabular}{|c|c|c|}
\hline \multirow{2}{*}{$\begin{array}{c}\text { Answer Choices } \\
\text { 'Price }\end{array}$} & \multicolumn{2}{|c|}{ Responses } \\
\hline & $73.08 \%$ & 38 \\
\hline - Convenience & $80.77 \%$ & 42 \\
\hline - Variety & $36.54 \%$ & 19 \\
\hline -Impulse & $7.69 \%$ & 4 \\
\hline - Word of Mouth & $9.62 \%$ & 5 \\
\hline - Ads on Mass Media (T.V, print, internet) & $7.69 \%$ & 4 \\
\hline Total Respondents: 52 & & \\
\hline
\end{tabular}

Q6: What are your biggest concerns about buying products online?

TABLE :6

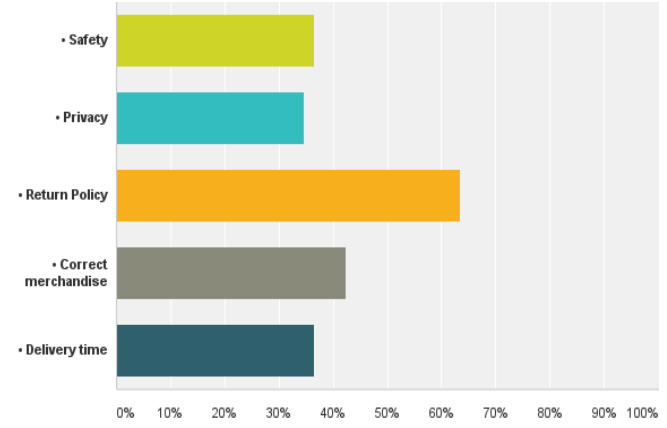

\begin{tabular}{l|ll}
\hline Answer Choices & Responses & 19 \\
\hline 'Sagetely & $36.54 \%$ & 18 \\
\hline 'Privacy & $34.62 \%$ & 33 \\
\hline 'Return Policy & $63.46 \%$ & 22 \\
\hline 'Correct merchandise & $42.31 \%$ & 19 \\
\hline 'Delivery time & $36.54 \%$ & \\
\hline Total Respondents: 52 & & \\
\hline
\end{tabular}

Convenience at $80.77 \%$ is the most important factor followed by Price at $73.08 \%$. Least important factors are impulse and ads on mass media at $7.69 \%$. This shows homemakers do not indulge in impulsive buying online. 
The biggest concern for homemakers regarding online buying is Return Policy at $63.46 \%$. Least concern is privacy at $34.62 \%$.

Q7: Which payment method do you use most often when buying products online?

\section{TABLE :7}

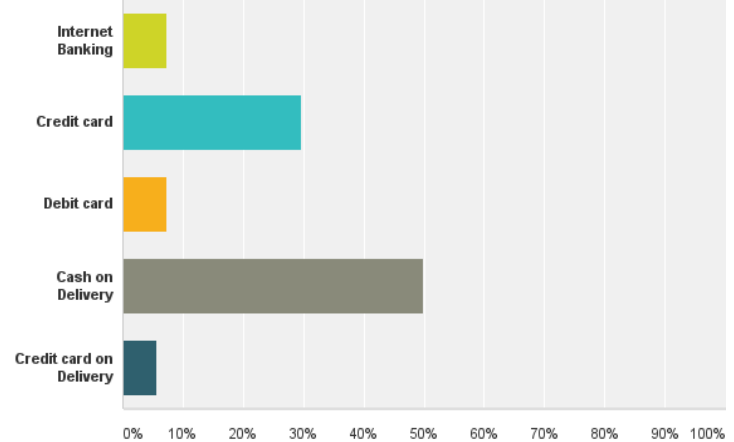

\begin{tabular}{l|lr}
\hline Answer Choices & Responses \\
\hline Internet Banking & $7.44 \%$ & 4 \\
\hline Credil card & $29.63 \%$ & 16 \\
\hline Debit card & $7.41 \%$ & 4 \\
\hline Cash on Delivery & $50.00 \%$ & 27 \\
\hline \multicolumn{1}{c}{ Credil card on Delivery } & $5.56 \%$ & 3 \\
\hline Total & & 54
\end{tabular}

Cash on delivery seems to be the most preferred mode of payment at $50 \%$. Only $5.56 \%$ prefer credit card on delivery. Homemakers are not still comfortable to pay online as there is a basic distrust with online retailers.

However according to a survey conducted by Nielsen, Indian netizens are the third largest credit card users for online shopping next to only Turkey and Ireland (Achille 2008; Express India 2008).

This proves that it maybe men/ professional women who are buying online more than the homemakers.

\section{Q8: Does social media trigger you to purchase a product/service online?}

\section{TABLE :8}

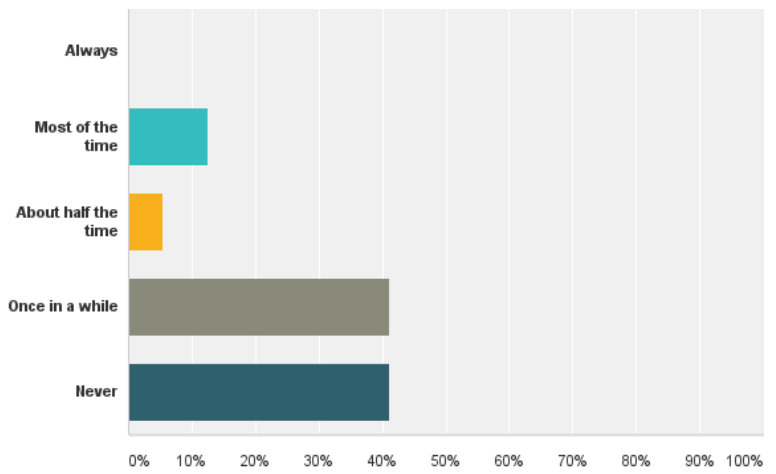

\begin{tabular}{l|ll}
\hline Answer Choices & Responses \\
\hline Always & $0.00 \%$ & 0 \\
\hline Nost of the time & $12.50 \%$ & 7 \\
\hline About hal the time & $5.36 \%$ & 3 \\
\hline Once in a while & $41.07 \%$ \\
\hline Never & & 23 \\
\hline Total Respondents: 56 & $41.07 \%$ & \\
\hline
\end{tabular}

Q9: What role does Social media play in your purchase decisions?.( Offline here means Physical stores)

TABLE :9

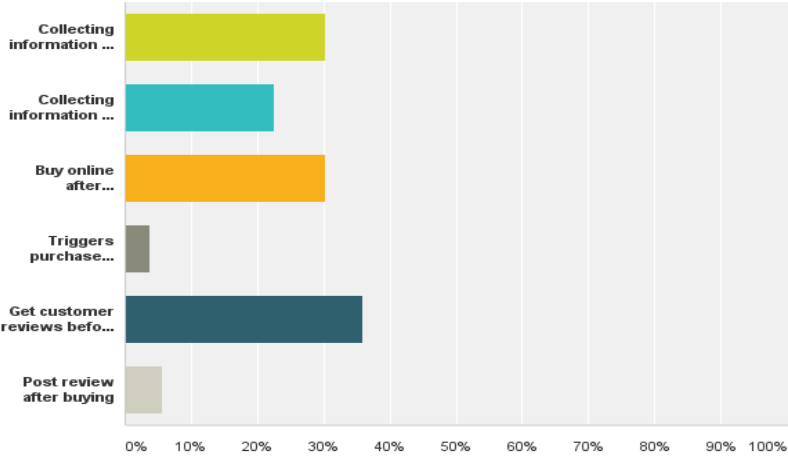

\begin{tabular}{|l|ll}
\hline Answer Choices & Responses \\
\hline Collecting information but buy offline & $30.19 \%$ & 16 \\
\hline Collecting information and buy online & $22.64 \%$ & 12 \\
\hline Buy online after collecting information offline & $30.19 \%$ & 16 \\
\hline Triggers purchase decision & $3.77 \%$ & 2 \\
\hline Get customer reviews before buying & $35.85 \%$ \\
\hline Post review after buying & 19 \\
\hline Total Respondents: 53 & $5.66 \%$ \\
\hline
\end{tabular}

$40.07 \%$ respondent agrees that either SNS trigger purchase online once in a while or never. Only 5.36 $\%$ feel SNS triggers them to purchase online about half of the times. It has important implication for digital 
marketers to rethink their communication strategies towards homemakers on SNS sites. Homemakers however do get led to the websites but only for seeking information.

$35.85 \%$ respondents feel that social media helps in getting customer review before buying. Only $3.77 \%$ think it helps trigger purchase decision. Seeking information to buy offline is clearly evident indicating that retailers with both physical as well an online stores have an advantage over pure e-tailers. This behaviour of shoppers has been termed as "showroomimg"

As per Neilsen Survey half the Indian consumers (50\%) use social media sites to help them make online purchase decisions. Online reviews and opinions are most important for Indians when buying Consumer Electronics (57\%), Software (50\%), and a Car (47\%).

Q10: What is the ticket value that you would purchase in a single purchase online.

TABLE :10

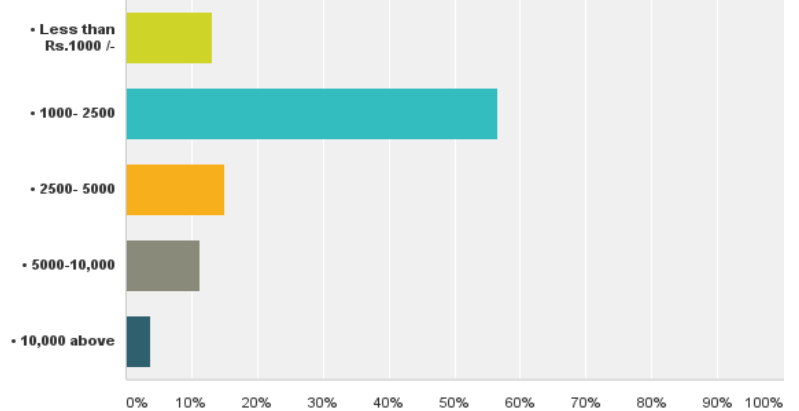

\begin{tabular}{|c|c|c|}
\hline Answer Choices & \multicolumn{2}{|c|}{ Responses } \\
\hline - Less than Rs.1000 / & $13.21 \%$ & 7 \\
\hline • 1000-2500 & $56.60 \%$ & 30 \\
\hline$\cdot 2500-5000$ & $15.09 \%$ & 8 \\
\hline - 5000-10,000 & $11.32 \%$ & 6 \\
\hline - 10,000 above & $3.77 \%$ & 2 \\
\hline Total & & 53 \\
\hline
\end{tabular}

Q11: What is the ticket value that you would purchase in a single purchase in a Physical Store ( e.g Shoppers' Stop, Crossword, local store etc)

TABLE :11

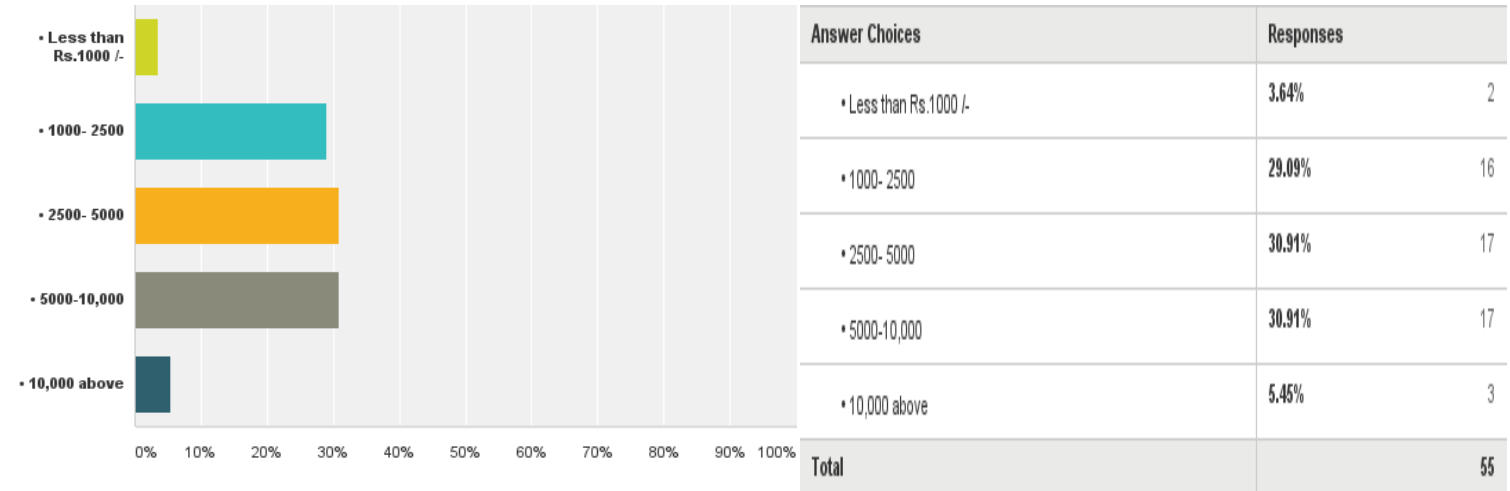

Majority of the respondents i.e. $56.60 \%$ will spend between 1000- 2500 rupees in a single purchase online. Only $3.77 \%$ will go beyond Rs. 10000/- in a single purchase. This shows that housewives buy more conservatively when online.

Offline $30.91 \%$ respondents may spend between $2500-10,000$. Only $5.45 \%$ will spend above 10,000/Offline, homemakers are comfortable buying more than planned or indulge in impulse buying. It shows their confidence as there is instant gratification.

Q12: Do you agree that information regarding products and services have a higher credibility on social media than on mass media channels because the information is beyond the company's control?

TABLE :12 


\begin{tabular}{l|l|l|l|l|l|l|}
$\begin{array}{l}\text { - Strongly } \\
\text { Agree }\end{array}$ & & Answer Choices & & \multicolumn{2}{c}{ Responses } \\
\hline \\
- Agree
\end{tabular}

Q13: In your opinion, which stage of your buying decision has been affected mostly because of social media? Rank on a scale of 1 to 5.1 being least, 5 being most.

TABLE :13

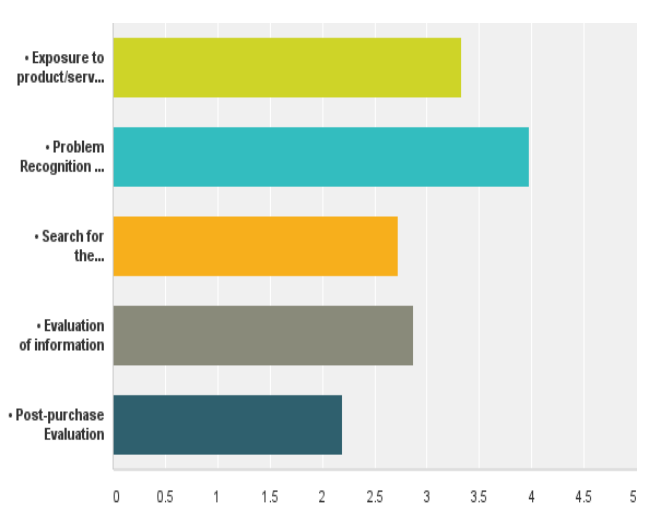

\begin{tabular}{|c|c|c|c|c|c|c|c|}
\hline & 1 & 2 & 3 & 4 & 5 & Total & $\begin{array}{l}\text { Average } \\
\text { Ranking }\end{array}$ \\
\hline - Exposure to product/service & $26.09 \%$ & $19.57 \%$ & $23.91 \%$ & $21.74 \%$ & $8.70 \%$ & & \\
\hline information & 12 & 9 & 11 & 10 & 4 & 46 & 3.33 \\
\hline - Problem Recognition ( need & $40.43 \%$ & $31.91 \%$ & $12.77 \%$ & $14.89 \%$ & $0.00 \%$ & & \\
\hline identification) & 19 & 15 & 6 & 7 & 0 & 47 & 3.98 \\
\hline \multirow[t]{2}{*}{ - Search for the atternatives } & $12.77 \%$ & $19.15 \%$ & $21.28 \%$ & $21.28 \%$ & $25.53 \%$ & & \\
\hline & 6 & 9 & 10 & 10 & 12 & 47 & 2.72 \\
\hline \multirow[t]{2}{*}{ - Evaluation of information } & $13.04 \%$ & $17.39 \%$ & $26.09 \%$ & $30.43 \%$ & $13.04 \%$ & & \\
\hline & 6 & 8 & 12 & 14 & 6 & 46 & 2.87 \\
\hline \multirow[t]{2}{*}{ - Post-purchase Evaluation } & $8.51 \%$ & $12.77 \%$ & $17.02 \%$ & $12.77 \%$ & $48.94 \%$ & & \\
\hline & 4 & 6 & 8 & 6 & 23 & 47 & 2.19 \\
\hline
\end{tabular}
mass media.

$46.43 \%$ are Neutral to this question. $42.86 \%$ believe that credibility is more on social media than on

$40.43 \%$ feel that social media helps in problem recognition. Only $8.51 \%$ use it for post purchase evaluation. SNSs primarily are contributing to the initial steps of the consumer buying process by creating awareness and need recognition with homemakers.

Q15: Time (approx.) spent on social media/ online sites per week

TABLE :15

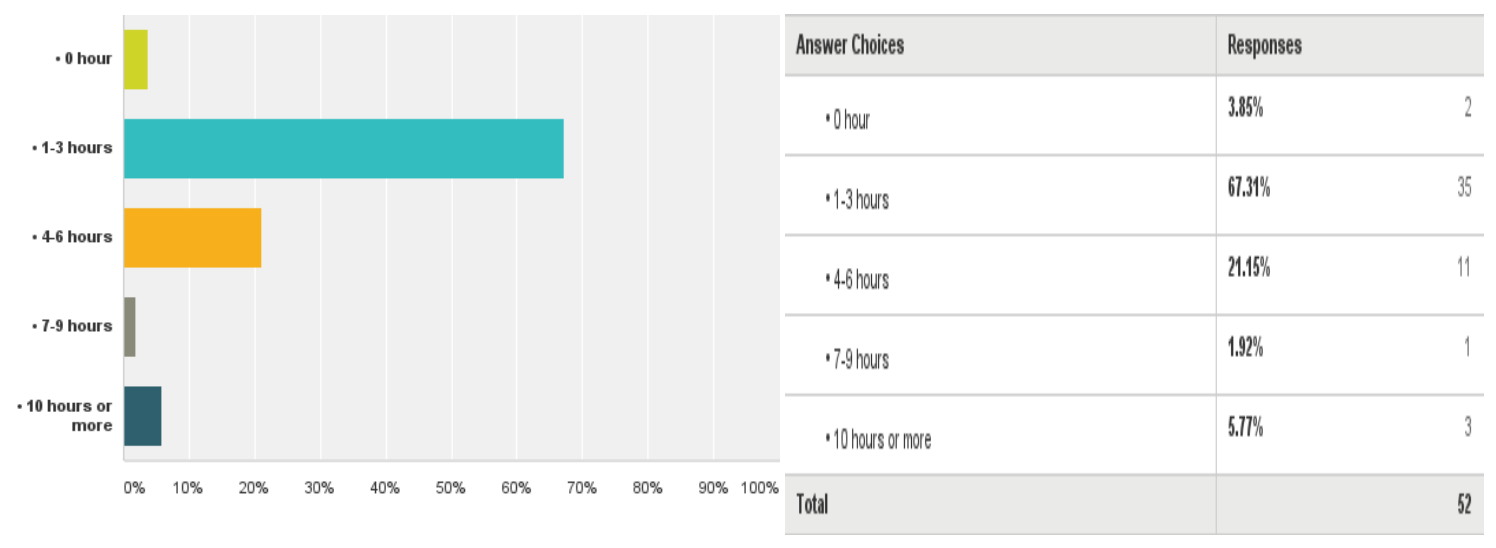

Q16: Which of the following social media sites you are using on a daily basis? (Please select all the platforms you are using)

TABLE :16 


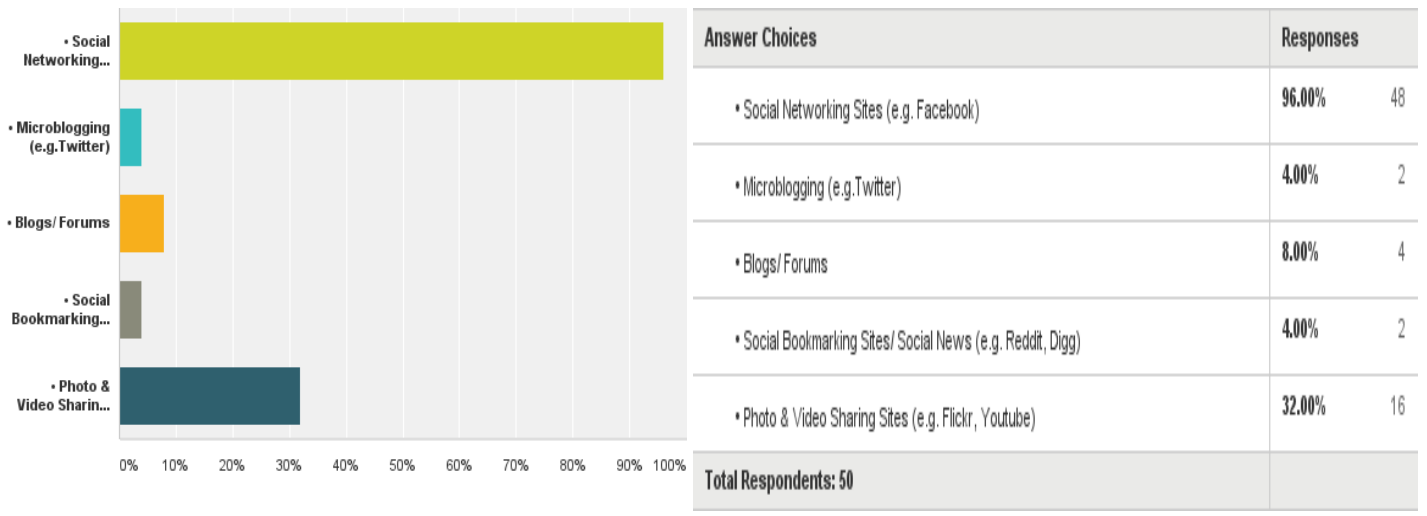

$67.31 \%$ respondents spend 1-3 hours per week on Social media and /or online sites. $3.85 \%$ of the respondents do not spend time online at all.

SNS are most widely used by homemakers at $96 \%$. Only $4 \%$ spend time on micro blogging or social bookmarking sites.

Q17: What age bracket do you belong to ?

TABLE :17

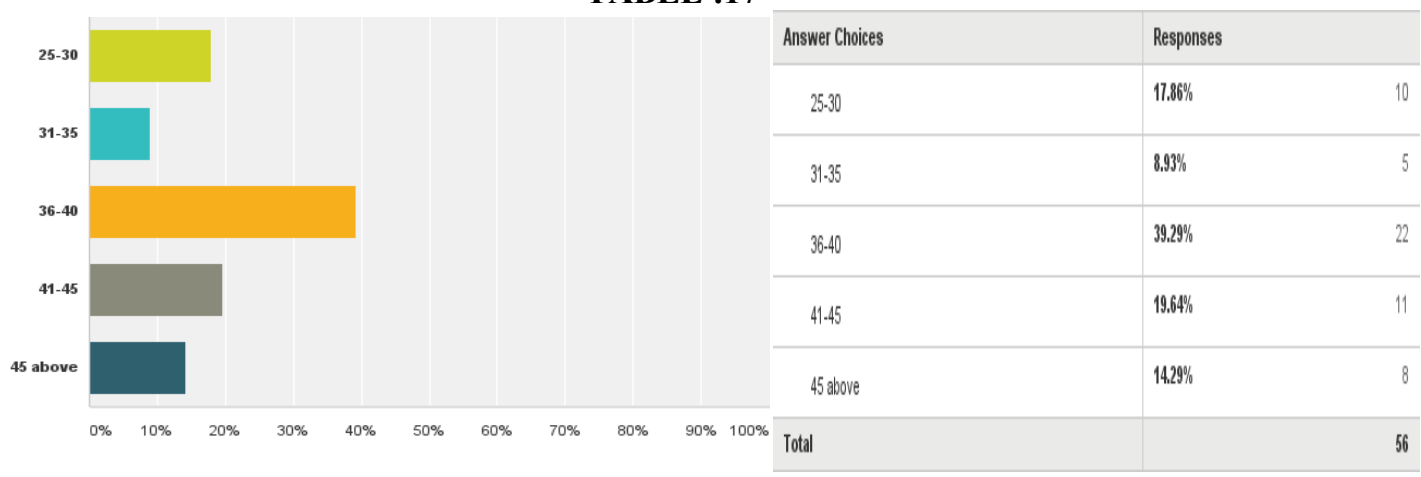

Q18: What is the total annual income of the HOUSEHOLD in which you live?

TABLE :18

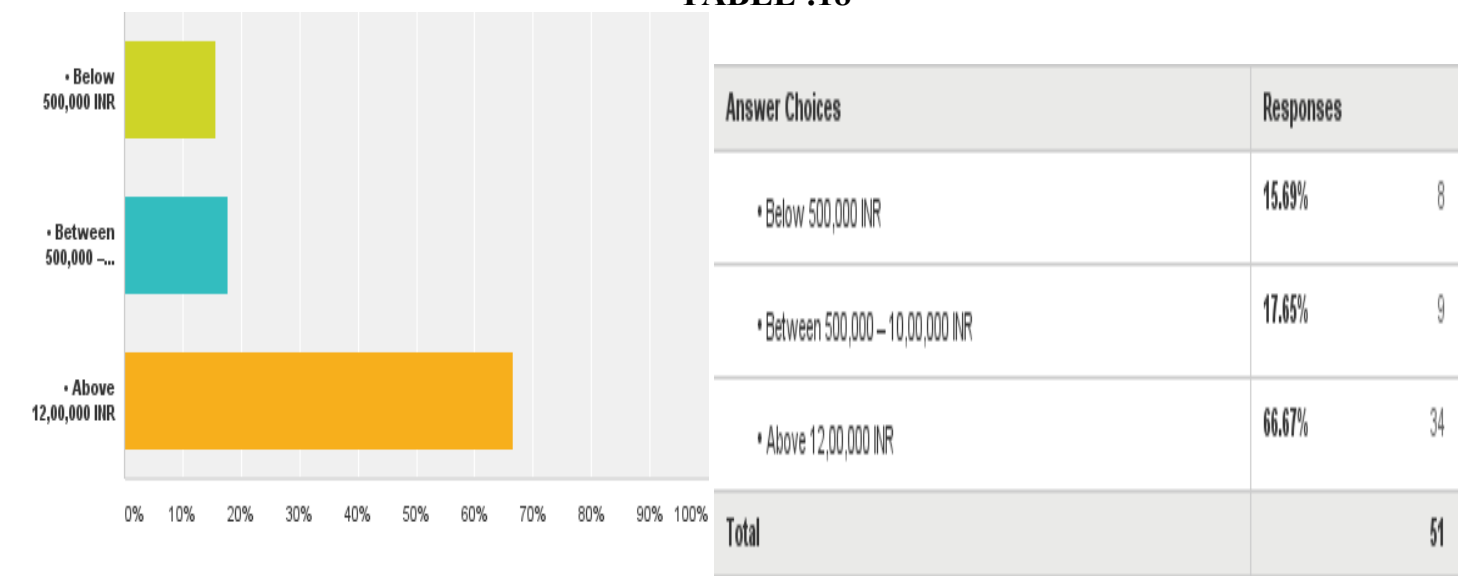

Q19: Do you have children?

TABLE :19 


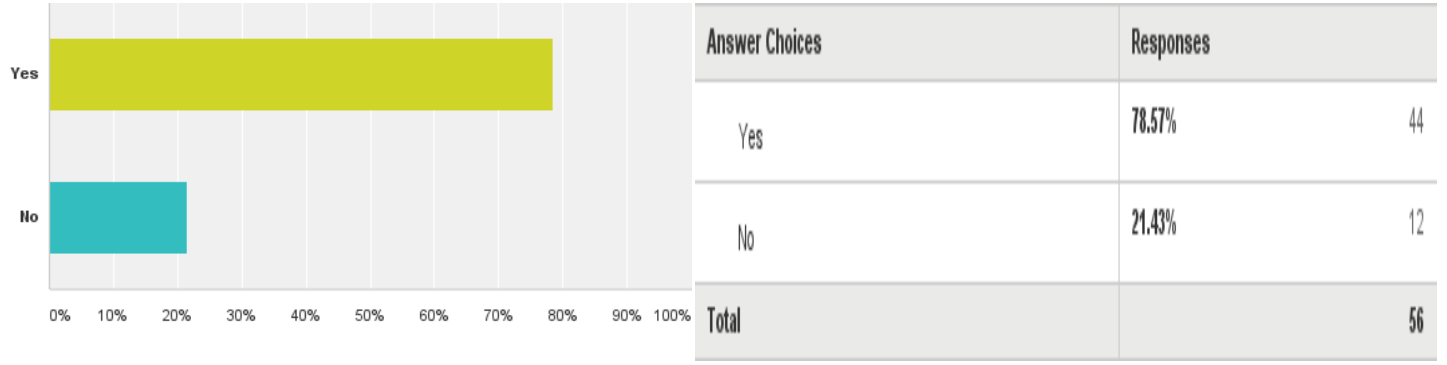

Majority of the respondents belong to $36-40$ age groups. Only $5 \%$ belong to the age group $31-35$. As per Nielsen report the demographic age group of $21-29$ at $48 \%$ is most active e-shoppers followed by the age group of $31-39$ at $28 \%$.

$66.67 \%$ respondents have an annual household income of above $12,00,000$ INR. $8 \%$ have below 5, 00,000. This shows in spite of disposable income this class of homemakers is actually not spending online.

$78.57 \%$ of the respondents have children and $21.43 \%$ do not have children. The presence of kids can have a direct co-relation with the amount spent on e-shopping.

\subsection{Qualitative Analysis:}

The Qualitative analysis throws up the following result.

The semi-structured discussion guide contained open-ended questions and cues in order to detect patterns and trends across the groups and encourage spontaneity. Sessions were recorded and later transcribed for analysis. Notes were taken of what were judged to be key constructs.

Most homemakers were mostly utilitarian in their shopping orientation.

What emerged from their conversation is the following:

What motivates you to buy online?

The answer was mainly discounts. One respondent stated that she wanted to buy a helmet which offline was costing her Rs. 1700 but when she looked for it online she got it for Rs. 900 .

They also said unless the discount was substantial they were not motivated to purchase online.

The online discounts on branded clothing like Vero Moda, Fcuk, Mango was substantially more (40\%) than the discounts offered by retailers offline (20\%).

However another respondent countered that benefit by pointing out that all merchandise of Vero-Moda online was a season old and not the latest. Therefore for a hedonistic shopper this does not work.

Does Social Media like Facebook ads influence you to buy?

All respondents unanimously responded 'no'. However they admitted, it does create curiosity and lead them to go to the sites for information seeking and awareness for future buying and comparison. One respondent said

"I love to know about things so that if I have to buy in future I don't have to hunt".

One respondent who has been buying clothes online for sometime admitted;

"I have got addicted to buying online."

However she bought only those clothing that did not require trial unlike a Jeans / Trousers. Also the buying was only for self and not for her husband or child. It was more of impulse buying.

What prevents you to from online buying?

Most of the respondents said they were not confident to purchase online.

One respondent said she was introduced to it buy her cousin in U.K. who instilled confidence in her. She started with the e-tailer Limeroad which happened to belong to her cousin's friend.

Privacy was also an important concern as they disliked intrusion into their private space inform of telemarketers, emails, mailers etc.

So we infer, somewhere there is a trust factor. Most women are in confident to buy because they do not trust the online retailers. Also we see social influence / recommendation has a strong role to play in changing attitudes towards shopping.

To one respondent shopping was a social cum psychological need. It helped beat depression and was for feel good factor which she felt online shopping could not satisfy. Also she felt online shopping was not trust 
worthy.

Which retailer do you prefer and why?

One respondent answered that although both Myntra and Jabong were good for clothing however with Jabong one need not make payment before delivery. One could try the merchandise and return immediately without any fuss.

This value proposition of Jabong which is "try and buy" is a strong differentiator and has great implications for the Marketers. It almost simulates the offline buying process.

What is your online shopping behaviour?

One respondent said internet shopping was boring. Too many options confused her. Another respondent said she often compares prices online and offline and finally makes purchase online. However she complained that there are times when you do not get your size or the same styles online.

What products do you buy online?

Books and Clothing were the two most preferred categories. Books it seems are more convenient to purchase online as its easily accessible, better organized. One respondent said she checks the books in physical stores but finally buys online because it offers better discounts.

However incase of mixer grinder her experience was different. She found the online picture very perfect however on checking it in a physical store she was disappointed by the actual quality of the product.

So we find that there are only limited categories of merchandise which consumers are willing to buy online for e.g books, clothing.

Another respondent said that online she compares all prices before buying but offline buying is more impulsive as the products remind her or nudge her to buy more.

"Invariably I end up buying more than planned when I go to D-mart", she comments.

"I rarely buy clothes online. I need to touch and feel". "The sales person makes me feel like a Queen." "He gives me personalized attention even during sale period."

These are some of the benefits which a consumer is deprived of in an online buying process.

Do you buy high value products online?

Most respondent had not ventured buying high value utilitarian products like fridge, television, air conditioner etc online. Only one respondent had bought her washing machine online and was happy with her purchase.

Do you post your reviews comments post purchase?

Rarely and only in extreme cases was the response. If an experience was too good or too bad then the respondent posted her reviews.

Have you purchase grocery and vegetables online?

All respondents answered in negative. They were happy with their local grocer and vegetable vendor who also delivered home free of cost. The prices were comparatively cheaper than the online grocer and quality better, they said. Also customer service was better with the grocers they patronized. One respondent related,

"My grocer agreed to replace the Rajma as it was not getting cooked easily. Such services cannot be expected from online grocers."

One respondent felt that delivery was an issue because one had to make sure to be home during the specified hours just to receive the consignment.

One respondent experienced some discrepancy in the billing and product ordered and was put -off by this experience.

Some respondents were willing to try.

Another respondent said the sight of fresh vegetables and fruits excited her. Also shopping from local vendor was a reason to step out. Her local vendor gave her Dhania for free which an online grocer won't oblige. The personal touch that a patronized vendor offers is missing online. Also in the net the bunch of Methi looks much bigger than in actual.

Do reviews, blog posts influence your purchase decision?

Most said yes. One respondent said she changed her holiday plans after reading reviews on SNS. 
So we infer that social media does influence the buying behaviour of consumers.

Do you prefer online shopping with all its benefits of price, convenience, variety or offline shopping? Why?

All respondent said they prefer to shop offline rather than online because they have time. Shopping is a leisure activity for them; they are used to this mode and mentally oriented towards offline. Shopping is also an experience, a family outing. Online shopping is limited in these terms. Lack of confidence and trust on e-tailers dissuades them from e-shopping.

Online shopping is also limited in the sense one cannot have trials and demo and take opinion from partners. Also on a very technical side, all brands follow different sizing, hence cannot make purchase without trial.

Do you agree review and blog posts on SNSs have higher credibility than on mass media?

Most respondents agreed. One respondent suspected that the reviews are at times fabricated.

\section{Conclusions}

Quantitative and Qualitative study undertaken points out that Home makers, are motivated by a variety of different reasons, including socializing and enjoyment. Despite the growth of Internet retailing (e-retailing), these social needs are largely unmet in e-shopping. In the high street, women do most of the shopping but online shopping (e-shopping) tends to be dominated by male shoppers. At the same time, social networking is growing fast and is especially popular amongst homemakers.

The study was conducted to understand the attitudes of Homemakers in Western suburbs of Mumbai toward online shopping. It shows that homemakers are both utilitarian as well as hedonistic shoppers. Shopping for them is an experience, leisure activities directed to reduce their boredom. The results divulge that majority of the subjects although are using online technologies for shopping but they prefer to shop offline. They are not confident to shop online as yet. Trust on e-tailers seems to be the hindering factor. Online shopping also does not satisfy their social and emotional needs. The study reveals that a big segment of the homemakers prefer to go to malls and spend money liberally but spend very conservatively online. The social factor, the touch and feel of merchandise, the market or store ambience, the interaction with sales person, the instant gratification of purchasing are certain factors which are missing in online shopping, the qualitative study reveals.

As homemakers are not pressed for time unlike their professional counterparts and also need a reason to go out and socialize, therefore online shopping for them is limited to books and small value items which offer heavy discounts. The study also reveals that the purchase ticket size is always more offline than online primarily because offline leads to impulse buying and immediate gratification.

Research indicates that for Indians shopping is a family event and reason for family outing. The study also reveals that the influence of social media is limited to creating awareness, generating curiosity leading to information search. It does not influence homemakers to buy.

Implications to Marketers: Homemakers make up a huge segment of educated, internet savvy and well disposed category of consumers who can be a potential profitable segment for e- marketers. Social media has not yet made a significant impact as desired in motivating them to buy online. Marketers should aim to not only create awareness and curiosity among this segment, instead use mass media and digital communication to create an attitude shift towards online buying. Marketers should closely analyse the factors that inhibit homemakers from shopping online and assuage their fears. Prominent celebrities/ opinion leaders should be roped in as role models.

The study indicates that Homemakers are generally online either in the afternoons or night after 9pm. Specific marketing activities should be addressed to the target audience around these times like "Happy Hours" or special discounts for household merchandise or beauty products.

E-tailers can address their concerns by making e-shopping more interactive ,have dedicated esalesperson for consultation in real time, make website more user friendly, include say an in-store music or create a technologically advanced 3D ambience, simulating real store experience. Marketers can build confidence in their consumers through initializing secure, reliable, and safe marketing platform and offering attractive proposition. 


\section{References}

[1]. Kotler Philip, 'Marketing Management', Prentice-Hall,12th Edition

[2]. Grant ,J, Isabel\& Stephen,R,G, 2005, 'Communicating culture: An examination of the buying behaviour of 'tweenage' girls and the key societal communicating factors influencing the buying process of fashion clothing ,'Journal of Targeting, Measurement and Analysis for Marketing,Palgrave Macmillan Ltd 1479-1862/06 \$30.00 Vol. 14, 2, 101-114 .

[3]. Diffley,S, Kearns, J,Bennet,W \& Kawalek,P 2011,'Consumer Behaviour in Social Networking Sites: Implications for Marketers,'Irish Journal Of Management.

[4]. Brown ,J,G,Durrett,R,J\& WetherbeJ,C, 2004, 'Consumer Reactions Towards Clicks and Bricks : Investigating Buying Behaviour On-line and at Stores, Behaviour \& Information Technology,' July-August 2004, Vol.23,No.4, 237-245.

[5]. KuruvillaS.J,Joshi,N\& Shah,N, 2009,' Do Men and Women Shop Differently? An Exploration Of Gender Differences In Mall Shopping In India', International Journal of Consumer Studies ISSN 1470-6423, 33 (2009) 715-723 (C) The Authors Journal compilation (C) 2009 Blackwell Publishing Ltd.

[6]. Dr. Rehman.K\&Ashfaq ,2011,' Examining Online Purchase Behaviou: A case of Pakistan, International Conference on Social Science and Humanity' IPEDR vol. 5(2011) IACSIT Press, Singapore.

[7]. Dr. Kumar, R,V \& Das,G,2009,'Impact of sales Promotion on Buyer Behaviour,' GlobsynManagement Journal,3,issue,1januaryJune 2009

[8]. Zheng,F, 2006 ' Internet Shopping and Its Impact on Consumer Behaviour,' University of Nottingham,

[9]. Dennis,C,Morgan,A,Wright.L.T\&Jayawardhena.C, 2010, 'The Influence of social e-Shopping in EnhancingYoung Women's Online Shopping Behaviour,' Journal Of Customer Behaviour, Vol.9, No.2,pp.151-174, ISSN1475-3928print/ISSN14776421 online CWestburnPublishersLtd.

[10]. Jacob,B \& deKlerk,H.M, 2010,' Online Shopping Behaviour of South African Professional Women: The role of consumers apparel Shopping Scripts,' International Journal of Consumer Studies 34(2010) 255-264 The Authors Jounal Compilation 2010 CBlackwell Publishing Ltd. ISSN 1470-6423

[11]. Sudhakar.A \& Rani,T.S, 2012,' Social Factors Influence On The Buying Behaviour Of Personal care Products,' SIES Journal Of Management, Septerber2012,Vol.8(2)

[12]. Packer,R, 2011, 'Social Media Marketing: The Art Of Conversational Sales,' WSI Social Media Strategist. Copyright@2011 RAM

[13]. http://www.livemint.com/Industry/9TZLjgWBwd4bU6K16POe1 M/Online-retail-at-126-bn-in-2013-up-33IAMAI.html?utm source=copy

[14]. http://www.ukessays.com/essays/marketing/online-shopping-in-india-marketing-essay.php

[15]. http://www.indianretailer.com/news/Nielsen-survey-on-consumer-buying-behaviour-4260/

[16]. http://www.ukessays.com/essays/marketing/analysis-of-impulse-buying-marketing-essay.php\#ixzz35NiXcG4K

\section{Bibliography:}

[17]. Hervé1, C \& Etienne, M 2009 , 'Age and factors influencing consumer behaviour,' International Journal of Consumer Studies 33 (2009) 302-308 (C) The Authors Journal compilation (C) 2009 Blackwell Publishing Ltd

[18]. Vyas, S,V,'2008,' Buying Behaviour of Mothers and Housewives for Milk Additives,' Journal of Marketing \& Communication ,January-April 2008Vol.3 Issue

[19]. Jacob,B \& deKlerk,H.M, 2010,' Online Shopping Behaviour of South African Professional Women: The role of consumers apparel Shopping Scripts,' International Journal of Consumer Studies 34(2010) 255-264 The Authors Jounal Compilation 2010 CBlackwell Publishing Ltd. ISSN 1470-6423

[20]. Sudhakar.A \& Rani,T.S, 2012,' Social Factors Influence On The Buying Behaviour Of Personal care Products,' SIES Journal Of Management, Septerber2012,Vol.8(2)

[21]. Kothari,CR., 'Research Methodology : Methods \& Techniques”, New Age International Publisher, Second Edition.

[22]. Bergh \&Behrer, 'How Cool Brands Stay Hot: Branding to Generation Y',Kogan Page.

\section{ANNEXURES :}

\section{QUESTIONNAIRE :}

1. How often do you buy products online?

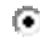

More than twice in a week

Once a week

Once a fortnight

Once a Month

Once in a 3 months

Other (please specify)

2. What types of products do you typically buy online? 


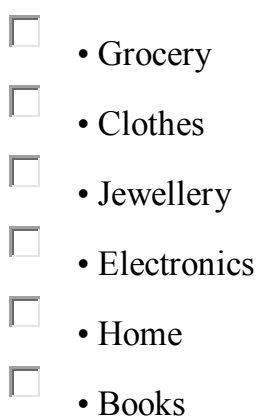

Other (please specify)

3. Which online retailers do you typically use?
- Amazon
Г Myntra
Г Snapdeal
- Flipkart
$\ulcorner$ - Local Banya

Other (please specify)

4. Which, according to you, is the most trusted online retailer and why?

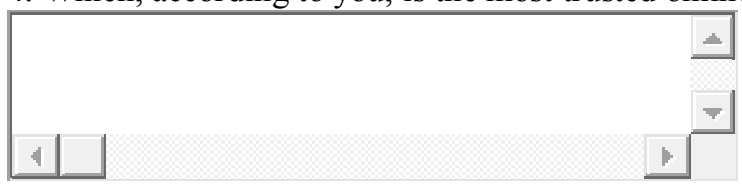

5. What triggers you to buy online?

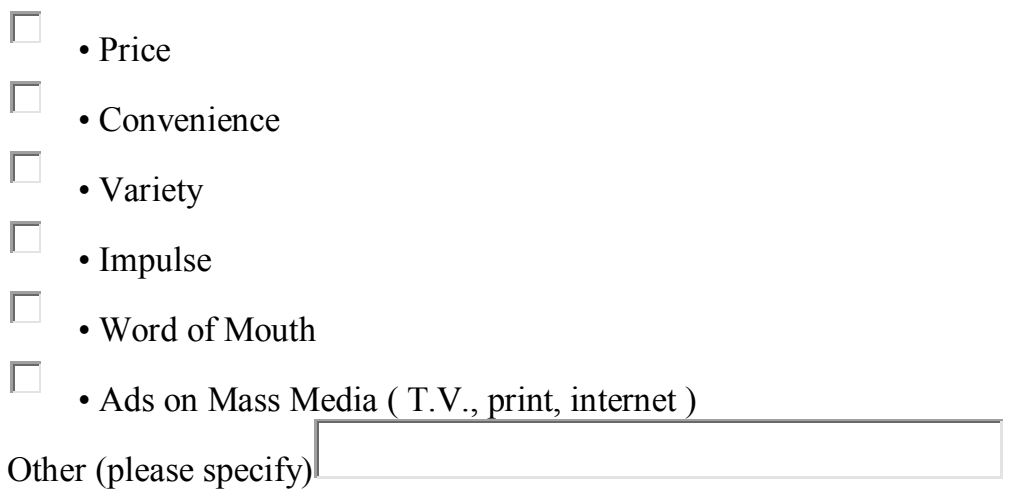

6. What are your biggest concerns about buying products online?
$\Gamma \cdot$ Safety
$\Gamma$ • Privacy
「 Return Policy 


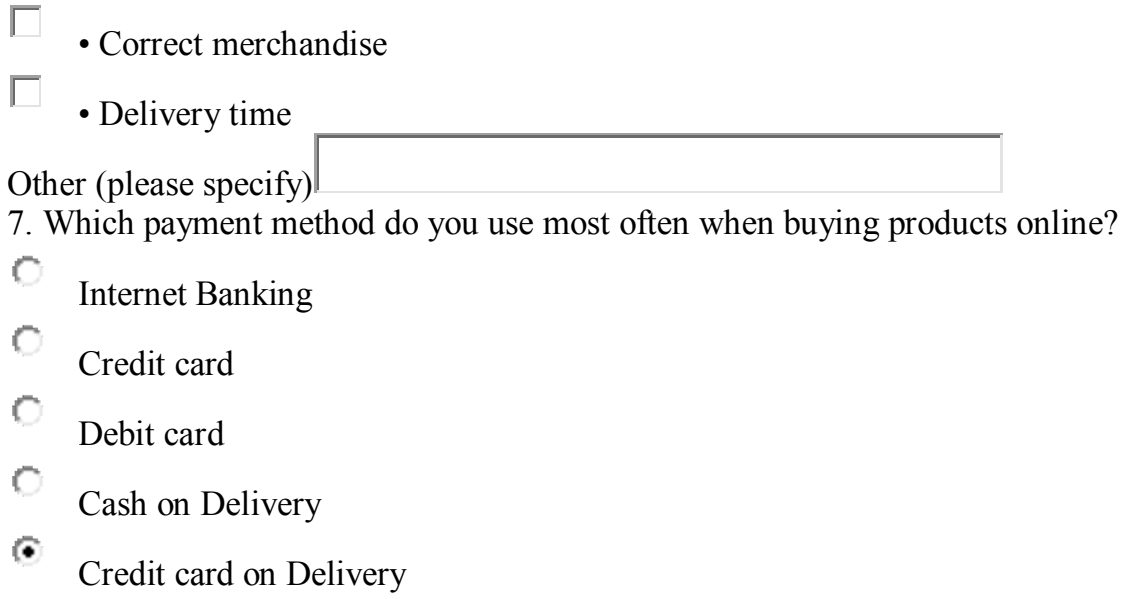

8. Does social media trigger you to purchase a product/service online?

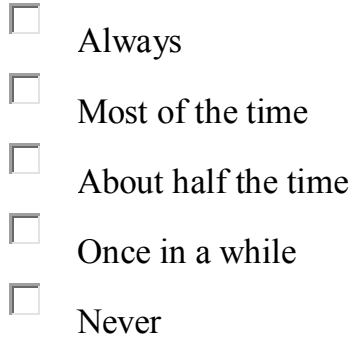

9. What role does Social media play in your purchase decisions?. ( Offline here means Physical stores)
$\Gamma$ Collecting information but buy offline
$\Gamma$ Collecting information and buy online
$\Gamma$ Buy online after collecting information offline
$\Gamma$ Triggers purchase decision
$\Gamma$ Get customer reviews before buying
$\ulcorner$ Post review after buying

Other (please specify)

10. What is the ticket value that you would purchase in a single purchase online.

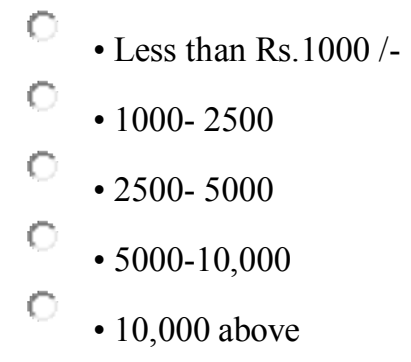

11. What is the ticket value that you would purchase in a single purchase in a Physical Store ( e.g Shoppers' Stop, Crossword, local store etc) 
- Less than Rs.1000/-

- $1000-2500$

-2500- 5000

- $5000-10,000$

- 10,000 above

12. Do you agree that information regarding products and services have a higher credibility on social media than on mass media channels because the information is beyond the company's control?

- Strongly Agree

- Agree

- Neutral

- Disagree

- Strongly Disagree

13. In your opinion, which stage of your buying decision has been affected mostly because of social media? Rank on a scale of 1 to 5 . 1 being least, 5 being most

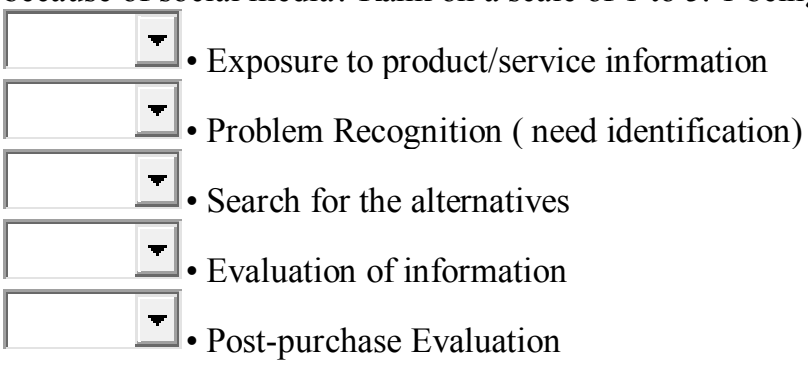

14. What time of the day are you most active on social media / online activity?

15. Time (approx.) spent on social media/ online sites per week

- 0 hour

(C) 1-3 hours

(C) 4-6 hours

(C) 7-9 hours

( 10 hours or more

Other (please specify)

16. Which of the following social media sites you are using on a daily basis? (Please select all the platforms you are using)

- Social Networking Sites (e.g. Facebook) 
- Microblogging (e.g.Twitter)

- Blogs/ Forums

$\Gamma$ - Social Bookmarking Sites/ Social News (e.g. Reddit, Digg)

• Photo \& Video Sharing Sites (e.g. Flickr, Youtube)

Other (please specify)

17. What age bracket do you belong to ?

25-30

(C) $31-35$

(C) $36-40$

(C) $41-45$

45 above

18. What is the total annual income of the HOUSEHOLD in which you live?

- Below 500,000 INR

- Between 500,000 - 10,00,000 INR

- Above 12,00,000 INR

19. Do you have children?

(- Yes

No 